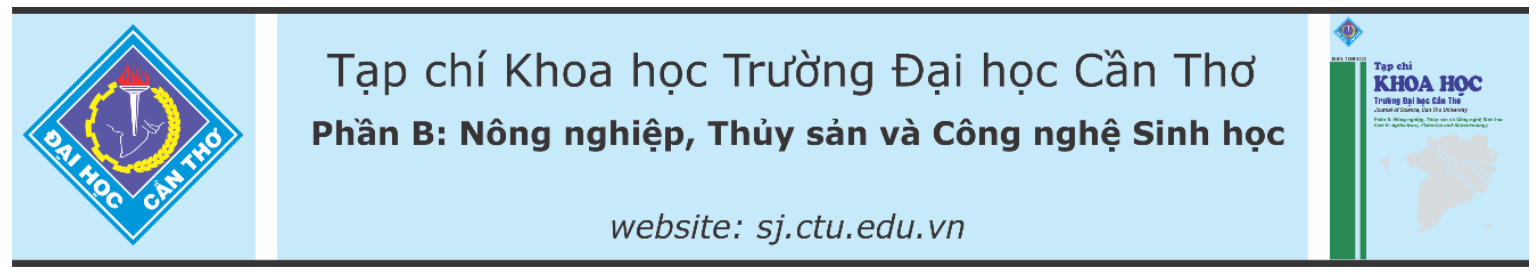

DOI:10.22144/ctu.jvn.2021.101

\title{
CHỌN LọC VI KHUẨN Bacillus sp. TÙ’ AO NUÔI TÔM QUẢNG CANH CÓ KHẢ NĂNG PHẦN HỦY HỬU CƠ VÀ KHÁNG Vibrio parahaemolyticus GÂY BỆNH TRÊN TÔM THË
}

Phạm Thị Tuyết Ngân*, Vũ Hùng Hải, Vũ Ngọc Út và Huỳnh Trường Giang

Bộ môn Thủy sinh hoc ưng dụng, Khoa Thủy sản, Truờng Đại hoc Cần Tho

*Nguròi chịu trách nhiệm về bài viết: Phạm Thị Tuyết Ngân (email: pttngan@ctu.edu.vn)

\section{Thông tin chung:}

Ngày nhận bài: 08/12/2020

Ngày nhận bài sủa: 16/01/2021

Ngày duyệt đăng: 25/06/2021

Title:

Selection of Bacillus sp. bacteria having organic mater decomposition ability and resistance to Vibrio parahaemolyticus causing disease in Penaeid shrimp

\section{Tù khóa:}

Ao tôm, Bacillus, kháng V. parahaemolyticus, phân hủy hĩu co

\section{Keywords:}

Against V. parahaemolyticus Bacillus, organic matter decomposition, shrimp ponds

\begin{abstract}
The present study was conducted to evaluate the ability of Bacillus sp., which was isolated from the extensive shrimp ponds (Tra Vinh, Bac Lieu and Ca Mau provinces), on organic matter decomposition and inhibition of pathogenic bacteria (Vibrio parahaemolyticus). The results showed that 83 selected strains of bacteria (44 strains had short rod-shaped, others had long rod-shaped and oval-shaped) were determined to be gram-positive, positive oxidase and catalase reactions, motile and sporeforming. This study also identified that 13 strains of bacteria (CM3.1, CM2.2, TV3.1, BT1.2, TV1.2, NH1.2, TB3.2, TB3.3, NH4.1, DH2.1, NH2.2, CN1.3, and TB4.3) were able to resist to $V$. parahaemolyticus. Among them, CM3.1 and TV1.3 exhibited high $\alpha$-amylase, protease, and cellulose enzyme activities, and could be used for future research to develop probiotic products for aquaculture.
\end{abstract}

\section{TÓM TẮT}

Nghiên cứu này được thực hiện nhằm đánh giá khả năng phân hủy vật chất hũu cơ và ức chế vi khuẩn gây bệnh (V. parahaemolyticus) của vi khuẩn Bacillus sp. phân lập tù bùn đáy ao nuôi tôm quảng canh (ở các tỉnh Trà Vinh, Bạc Liêu và Cà Mau). Kết quả đã thu được 83 chủng vi khuẩn (44 chủng có hình que ngắn, số còn lại có hình que dài và oval) được xác định là Gram duoong, phản úng oxidase và catalase duoong tính, có khả năng di động và hình thành bào tử. Mười ba chủng (CM3.1, CM2.2, TV3.1, BT1.2, TV1.2, NH1.2, TB3.2, TB3.3, NH4.1, DH2.1, NH2.2, CN1.3, TB4.3) có khả năng kháng với $V$. parahaemolyticus (đuờng kính kháng khuẩn 2,05-13,05 mm). Trong số các chủng này, CM3.1 và TV1.3 có hoạt tính enzyme a-amylase, protease, cellulose cao có thể sử dụng cho các nghiên cứu tiếp theo để phát triển chế phẩm vi sinh phục vu nuôi trồng thủy sản.

\section{GIỚI THIÊU}

Sử dụng kháng sinh trong phòng trị bệnh cho tôm nuôi đã gây hiện tượng kháng thuốc, vì vậy chế phẩm vi sinh đã trở thành một trong những cách tiếp cận mới được ứng dụng rộng rãi. Tuy nhiên phần lớn các chế phẩm vi sinh sử dụng trong nước hiện nay đều có nguồn gốc ngoại nhập hoặc không rõ thành phần, chủng loại. Các chế phẩm vi sinh phân lập và sản xuất trong nước vẫn còn hạn chế. Việc nghiên cứu chọn lựa các dòng vi khuẩn hữu ích bản 
địa làm cơ sở cho việc sản xuất đại trà chế phẩm vi sinh là rất cần thiết và có ý nghĩa thực tiễn trong giai đoạn hiện nay nhằm nâng cao hiệu quả sản xuất, hạn chế ô nhiễm môi trường, thúc đẩy và tăng cường sự bền vững của nghề nuôi. Những vi khuẩn hữu ích có tiềm năng được phân lập trực tiếp từ môi trường nuôi có hiệu quả hầu hết là các loài Bacillus nhu $B$. subitilis, B. amyloliquefaciens, B. licheniformis,... (Burford et al., 1998). Ngoài ra, khi Bacillus, Nitrosomonas và Nitrobacter được bổ sung vào ao nuôi, các chỉ tiêu thủy lý hóa được cải thiện rõ rệt. Vi khuẩn Bacillus spp. là một trong các nhóm được nghiên cứu nhiều nhất, có khả năng sản sinh nhiều sản phẩm biến dưỡng thứ cấp như kháng sinh, thuốc trừ sâu sinh học, hóa chất và enzyme (Ferarri et al., 1993). Do đó, nghiên cứu được thực hiện nhằm đánh giá khả năng phân hủy chất hữu cơ và ức chế sự phát triển của vi khuẩn Vibrio giúp chọn lọc vi khuẩn Bacillus sp. có tiềm năng probiotic để sản xuất chế phẩm vi sinh phục vụ nuôi trồng thủy sản.

\section{PHƯƠNG PHÁP NGHIÊN CÚU}

\subsection{Phương pháp thu mẫu nền đáy}

Mẫu bùn đáy ao tôm nuôi quảng canh (36 ao) ở các tỉnh Trà Vinh, Bạc Liêu, Cà Mau được thu bằng hệ thống $\mathrm{PVC}$ (đã tiệt trùng bằng dung dịch cồn $\left.70^{\circ} \mathrm{C}\right)$. Tại mỗi ao, mẫu bùn được thu ở 3 vị trí: đầu ao, giữa ao và cuối ao theo một đường chéo. Mẫu được giữ lạnh và chuyển về phòng thí nghiệm trong vòng 3-5 giờ, sau đó được bảo quản ở $4^{\circ} \mathrm{C}$ và xử lý trong vòng 2 giờ. Các thông tin như tên ao, ngày tháng và thời gian thu mẫu được ghi đầy đủ trên nhãn dán dụng cụ thu mẫu (Somsiri et al., 2006).

\subsection{Phân lập vi khuẩn Bacillus spp. từ mẫu bùn đáy ao}

Vi khuẩn Bacillus spp. được phân lập theo mô tả Boottanun et al. (2017) với một vài thay đổi. Một gram mẫu bùn đã được pha vào $9 \mathrm{~mL}$ nước muối $(0.85 \% \mathrm{NaCl})$ tiệt trùng và xử lý nhiệt ở $80^{\circ} \mathrm{C}$ trong 20 phút. Sau đó, $100 \mu \mathrm{L}$ mẫu dung dịch pha loãng ở nồng độ thích hợp $\left(10^{-1}, 10^{-2}, 10^{-3}\right)$ được trải đều trên đĩa thạch Nutrient Agar (NA), ủ ở $28^{\circ} \mathrm{C}$ trong 24 giờ. Các khuẩn lạc đơn được chọn và cấy ria nhiều lần trên đĩa thạch NA để thu khuẩn lạc thuần. Các chủng phân lập được định danh và trữ lạnh ở $-80^{\circ} \mathrm{C}$ trong môi trường Nutrient Broth (NB) với $20 \%$ glycerol cho các thí nghiệm sau.

\subsection{Phương pháp định danh vi khuẩn bằng phép thử sinh hóa}

Các chủng vi khuẩn thuần phát triển trên môi trường NA được quan sát đặc điểm hình thái tế bào bằng kính hiển vi quang học (Olympus $\mathrm{BX} 50$,
Olympus, Tokyo, Japan) và kiểm tra các chỉ tiêu cơ bản nhu:

Nhuộm Gram: độ thuần và hình thái của các chủng vi khuẩn được quan sát bằng tiêu bản nhuộm Gram theo phương pháp Hucker and Conn (1923). Dùng que cấy vô trùng lấy một ít khuẩn lạc đã tách ròng hòa vào giọt nước muối sinh lý đã tiệt trùng ở giữa phiến kính, để khô trong phòng thí nghiệm. Cố định tiêu bản bằng cách hơ nhanh trên ngọn lửa đèn cồn 2-3 lần để vi khuẩn gắn chặt vào phiến kính. Sau đó tiến hành nhuộm với dung dịch tím tinh thể (Crystal Violet) trong 1 phút, rửa lại bằng nước cất. Nhuộm tiếp bằng dung dịch lugol trong 1 phút, rửa bằng nước cất. Nhuộm tiếp bằng dung dịch lugol trong 1 phút, rửa bằng nước cất. Nhỏ $1-2$ giọt dung dịch alcohol $95 \%$ cho đến khi mất màu, rửa lại bằng nước cất. Sau đó nhuộm tiếp dung dịch safranin trong 1 phút, rửa nước cất, để khô. Quan sát với giọt dầu ở vật kính $100 \mathrm{x}$. Nếu nhuộm đúng vi khuẩn Gram dương bắt màu tím, Gram âm bắt màu hồng.

Phản ứng catalase: que cấy vô trùng được dùng để lấy một ít khuẩn lạc phết lên lam kính, sau đó nhỏ một giọt dung dịch $\mathrm{H}_{2} \mathrm{O}_{2}(3 \%)$ lên lame. Vi khuẩn cho phản ứng dương tính với catalase sẽ có hiện tượng sủi bọt khí và ngược lại.

Phản úng oxidase: một ít vi khuẩn được phết lên đĩa giấy đã tẩm dung dịch Tetramethyl - $\mathrm{p}$ Phenylendiamin dihydrochlorid $(1 \%)$ bằng que cấy vô trùng. Vi khuẩn cho phản ứng dương tính sẽ làm giấy chuyển sang màu đen và ngược lại.

Tính di động: một giọt nước cất được nhỏ lên lam kính, sau đó dùng que cấy vô trùng trải đều vi khuẩn lên lam, đậy bằng lamen và quan sát bằng kính hiển vi ở vật kính 100 x.

\subsection{Sàng lọc các chủng vi khuẩn có khả năng kháng V. parahaemolyticus}

Các chủng phân lập được khảo sát hoạt tính kháng khuẩn $V$. parahaemolyticus bằng phương pháp cấy vệt vuông góc (Lertcanawanichakul and Sawangnop, 2011; Thongjun et al., 2016). Vi khuẩn $V$. parahaemolyticus được sử dụng là chủng gây bệnh hoại tử gan tụy cấp trên tôm thuộc bộ sưu tập vi khuẩn của Bộ môn Thủy sinh học Ứng dụng, Khoa Thủy sản, Trường Đại học Cần Thơ, có nguồn gốc từ ao tôm (Lê Thế Xuân, 2019). Vi khuẩn $V$. parahaemolyticus được phục hồi và nuôi tăng sinh trong môi trường Trypto-casein Soy Borth (TSB) (bổ sung $1 \% \mathrm{NaCl}$ ) ở $30^{\circ} \mathrm{C}$. Sau 12 giờ nuôi, huyền phù vi khuẩn được chỉnh mật độ $10^{6} \mathrm{CFU} / \mathrm{mL}$ (ở OD $600 \mathrm{~nm}$ ). Các chủng Bacillus phân lập được cấy dọc theo một đường thẳng trên môi trường Tryptocasein Soy Agar (TSA) (bổ sung $1 \% \mathrm{NaCl}$ ) và ủ ở 
$30^{\circ} \mathrm{C}$. Sau 48 giờ, tiến hành cấy vi khuẩn $V$. parahaemolyticus (mật độ $10^{5} \mathrm{CFU} / \mathrm{mL}$ ) theo vạch ngang vuông góc với vạch vi khuẩn Bacillus đã phát triển, tiếp tục ủ ở $30^{\circ} \mathrm{C}$ trong 24 giờ. Khả năng kháng khuẩn được xác định bằng cách đo khoảng cách vùng vô trùng theo đơn vị mm dựa theo Hutt et al. (2006). Mỗi thí nghiệm được lặp lại 2 lần.

\section{5. Đánh giá hoạt tính kháng $V$. parahaemolyticus bằng phương pháp đồng nuôi cấy}

Thí nghiệm được thực hiện dựa theo báo cáo trước đây của Kewcharoen and Srisapoome (2019) như sau: vi khuẩn tiềm năng và vi khuẩn gây bệnh $V$. parrahaemolyticus được chuẩn bị theo phương pháp được mô tả mục 2.4 và huyền phù của mỗi vi khuẩn (mật độ $1 \times 10^{5} \mathrm{CFU}$ ) được đồng nuôi cấy trong $10 \mathrm{~mL}$ TSB (bổ sung $1 \% \mathrm{NaCl}$ ) và ủ ở $30^{\circ} \mathrm{C}$. Nghiệm thức đối chứng được chuẩn bị riêng biệt với chủng tiềm năng và vi khuẩn gây bệnh ở cùng một điều kiện. Mật độ vi khuẩn Bacillus và Vibrio được đánh giá ở các mốc thời gian $0,24,48,72,96,120$ giờ nuôi cấy bằng phương pháp cấy đĩa thạch trên môi trường $\mathrm{NA}$ và Thiosulfate Citrate Bile Salts Sucrose (TCBS agar).

\section{6. Đánh giá hoạt tính enzyme ngoại bào}

Ly trích enzyme: các chủng vi khuẩn tiềm năng được nuôi trong môi trường Minimal Broth (gồm 6 $\mathrm{g} \mathrm{Na}_{2} \mathrm{HPO}_{4}, 3 \mathrm{~g} \mathrm{KH}_{2} \mathrm{PO}_{4}, 0.5 \mathrm{~g} \mathrm{NaCl}, 1$ g NH $4 \mathrm{Cl}$ và $1000 \mathrm{~mL}$ nước cất) bổ sung lần lượt $1 \%$ casein/starch/carboxy-methylcellulose, ủ trên máy lắc ở $30^{\circ} \mathrm{C}$. Sau 24 giờ nuôi, ly tâm huyền phù ở tốc độ $10.000 \mathrm{rpm}$ trong 10 phút ở $4^{\circ} \mathrm{C}$ để loại bỏ tế bào vi khuẩn và thu phần dịch nổi phía trên (Cell-free supernatant, CFS) để xác định hoạt tính enzyme protease, $\alpha$-amylase, cellulose (Fernandes et al., 2019).

Hoạt tính protease được xác định dựa theo phương pháp Huynh et al., (2018) như sau: $100 \mu \mathrm{L}$ dịch enzyme ủ với $100 \mu \mathrm{L}$ dung dịch $1 \%$ casein (pha trong dung dịch đệm Tris-HCl, $\mathrm{pH}$ 7.0) trong 10 phút ở $37^{\circ} \mathrm{C}$ và $500 \mu \mathrm{L}$ dung dịch $5 \%$ trichloroacetic acid được thêm vào để ngừng phản ứng. Sau 20 phút, hồn hợp trên được ly tâm ở tốc độ 3000 rpm trong 10 phút ơ $4^{\circ} \mathrm{C}$ và thu phần dịch nổi bên trên để xác định hoạt tính enzyme theo phương pháp Lowry. Một unit (UI) enzyme tương ứng với lượng enzyme phóng thích $1 \mu \mathrm{g}$ tyrosine ở cùng điều kiện chuẩn.

Hoạt tính $\alpha$-Amylase thực hiện bằng phương pháp Starch-Iodine được mô tả theo Abd-Elhalem et al. (2015) với một vài thay đổi. Trước hết, $1 \mathrm{~mL}$ dịch CFS ủ với $1 \mathrm{~mL}$ dung dịch $1 \%$ soluble starch (pha trong dung dịch Phosphate Buffer 0.1 M, pH 7.0) trong ống nghiệm thủy tinh ở $60^{\circ} \mathrm{C}$ trong 30 phút. Sau đó, thêm lần lượt $1 \mathrm{~mL} \mathrm{HCl} 1 \mathrm{M}$ vào để ngừng phản ứng và $1 \mathrm{~mL}$ thuốc nhuộm Iodine $(5 \mathrm{mM} \mathrm{I} 2$ và $5 \mathrm{mM} \mathrm{KI}$ ) để hình thành phản ứng màu và đo độ hấp thụ bằng phương pháp so màu quang phổ ở bước sóng $620 \mathrm{~nm}$. Hoạt tính enzyme được xác định tương ứng với một đơn vị hồ hóa $1 \mathrm{mg}$ starch mỗi giây trong phản ứng.

Hoạt tính enzyme cellulose được xác định theo phương pháp của Ghose (1987) với một vài thay đổi. Phản ứng bao gồm $0,5 \mathrm{~mL}$ dung dịch $1 \% \mathrm{CMC}$ (được chuẩn bị trong dung dịch đệm citrate $0.05 \mathrm{M}$, $\mathrm{pH}$ 5) và $0,5 \mathrm{~mL}$ dịch enzyme vi khuẩn được ủ ở $50^{\circ} \mathrm{C}$ trong 30 phút, sau đó thêm $1,5 \mathrm{~mL}$ dung dịch thuốc thử DNS (Miller, 1959) vào phản ứng và đun nóng $100^{\circ} \mathrm{C}$ trong 10 phút. Sau đó, đo độ hấp thụ ở bước sóng $540 \mathrm{~nm}$ bằng phương pháp so màu quang phổ. Một unit (UI) enzyme được xác định như lượng enzyme phóng thích $1 \mu \mathrm{mol}$ glucose ở cùng điều kiện chuẩn.

\subsection{Thí nghiệm đánh giá độ an toàn sinh học}

Thí nghiệm được thực hiện nhằm đánh giá mức độ an toàn sinh học của chủng vi khuẩn tiềm năng trên tôm thẻ chân trắng dựa theo thí nghiệm đã báo cáo của Yun et al. (2019) với một vài thay đổi như sau: tôm thẻ chân trắng (trọng lượng $4 \pm 1 \mathrm{~g}$ ) từ trại thực nghiệm (Bộ môn Thủy sinh học ứng dụng, Khoa Thủy sản, Trường Đại học Cần Thơ) được thuần ở độ mặn $10 \%$, sau đó tôm được bố trí vào bể chứa $5 \mathrm{~L}$ nước có độ mặn $10 \%$ với mật độ 10 con/bể. Thí nghiệm gồm hai nghiệm thức: đối chứng (không bổ sung) và nghiệm thức bổ sung vi khuẩn (liều lượng khoảng $5 \times 10^{8} \mathrm{CFU} / \mathrm{mL}$ ). Mỗi nghiệm thức được lặp lại ba lần. Chủng vi khuẩn được nuôi trong môi trường Nutrient Borth $(\mathrm{NB})$, sinh khối tế bào được thu bằng phương pháp ly tâm và rửa lại hai lần bằng nước muối sinh lý $(0,85 \% \mathrm{NaCl})$, sau đó chỉnh mật độ quang $\mathrm{OD}_{600}=1$ (tương ứng với $5 \times$ $10^{8} \mathrm{CFU} / \mathrm{mL}$ ). Ở nghiệm thức bổ sung, $5 \mathrm{~mL}$ huyền phù tế bào được cấy vào bể trong khi đó ở nghiệm thức đối chứng $5 \mathrm{~mL}$ nước muối sinh lý được thêm vào. Trong quá trình thí nghiệm, tôm được cho ăn bình thường ( $3 \%$ trọng lượng tôm) và thay nước mỗi ngày. Sau mỗi lần thay nước, huyền phù tế bào và nước muối sinh lý được chuẩn bị và bổ sung vào bể như phương pháp đề cập ở trên. Tỉ lệ sống của tôm đã được ghi nhận và so sánh sau bảy ngày thí nghiệm.

\subsection{Phương pháp xử lý số liệu}

Số liệu thu thập được tính toán giá trị trung bình, độ lệch chuẩn bằng phần mềm Microsoft Excel 2016 
và so sánh sự khác biệt giữa các nghiệm thức theo phương pháp phân tích ANOVA một nhân tố với phép thử Duncan bằng phần mềm thống kê SPSS 25.0 ở mức ý nghĩa $(\mathrm{p}<0,05)$.

\section{KẾT QUẢ VÀ THẢO LUẬN}

\subsection{Phân lập vi khuẩn Bacillus spp. từ mẫu bùn đáy ao}

Dựa vào hình thái khuẩn lạc của vi khuẩn Bacillus spp. được mô tả bởi Boottanun et al.,
(2017) đã chọn được 83 chủng vi khuẩn thuộc giống Bacillus phát triển trên môi trường NA. Ở $30^{\circ} \mathrm{C}$ sau 24 giờ cấy, hầu hết các chủng đều có khuẩn lạc dạng nhỏ tròn, bìa tròn đồng tâm, có một số khuẩn lạc dạng to tròn, bìa tròn không tâm nhẵn, kích thước dao động từ $0,3-3,1 \mathrm{~mm}$. Đa số khuẩn lạc có màu trắng đục, bìa tròn răng cưa, tròn không tâm 47 loài $(56,6 \%)$ và khuẩn lạc màu trắng trong, bìa tròn đồng tâm, tròn đồng tâm nhẵn 36 loài $(43,4 \%)$, (Hình 1).

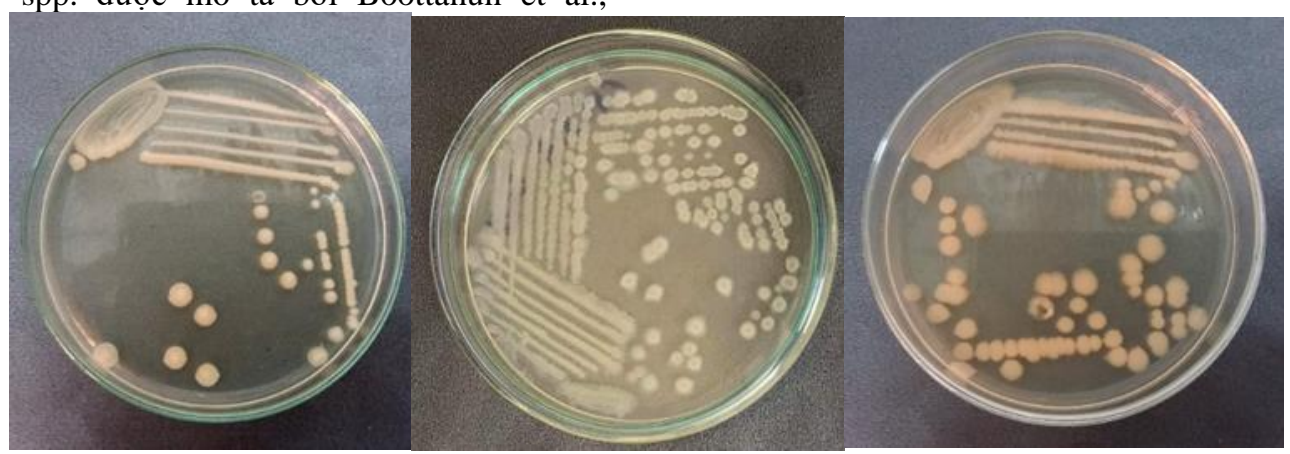

Hình 1. Một số hình thái khuẩn lạc Bacillus trên môi trường NA

\section{2. Đặc điểm sinh hóa}

Qua kết quả nhuộm Gram đã chọn được 44 chủng (tổng số 83 chủng) bắt màu tím xanh là vi khuẩn gram dương. Quan sát hình dạng tế bào ở độ phóng đại $40 \mathrm{X}$ xác định hầu hết các tế bào vi khuẩn có dạng hình que, một số hình cầu xếp thành chuổi hoặc xếp riêng lẻ. Trong đó, que ngắn có 42 chủng (50,6\%), oval có 20 chủng $(24,1 \%)$, que dài có 17 chủng $(20,5 \%)$, và 4 chủng hình cầu to $(4,8 \%)$. Tất cả 44 chủng đều có khả năng di động và sinh bào tử. Đồng thời, các chỉ tiêu sinh hóa khi thử nghiệm catalase và oxydase đều dương tính tương đồng với các đặc tính của giống Bacillus. Vì thế, tất cả chủng vi khuẩn Bacillus tiềm năng phần lớn có hình dạng que ngắn, một số có hình dạng que dài và oval. Các chủng vi khuẩn Bacillus có phản ứng catalase, oxydase đều dương tính, đều di động và có khả năng hình thành bào tử (Phạm Thị Tuyết Ngân 2012).

\subsection{Hoạt tính kháng vi khuẩn $\mathrm{V}$. parahaemolyticus}

Kết quả đánh giá khả năng kháng khuẩn bằng phương pháp cấy vệt cho thấy trong 44 chủng Bacillus sp. có 13 chủng có khả năng kháng khuẩn bao gồm: CM3.1, CM2.2, TV3.1, BT1.2, TV1.2,
NH1.2, TB3.2, TB3.3, NH4.1, DH2.1, NH2.2, CN1.3, TB4.3 với đường kính kháng khuẩn dao động từ 2.05-13.05 mm (Bảng 3). Balcázar et al. (2007) đã phân lập được $B$. subtilis UTM 126 có hoạt động ức chế ba chủng $V$. harveyi, $V$. alginolyticus và $V$. parahaemolyticus phân lập từ tôm bị bệnh với vòng kháng khuẩn khoảng 10 - 15 mm. Theo Mahdhi et al. (2010), các chủng $B$. subtilis và $B$. coagulans được phân lập từ môi trường Artemia có khả năng đối kháng $V$. parahaemolyticus ATCC17802, V. alginolyticus ATCC17749 và $V$. alginolyticus với vòng kháng khuẩn dao động từ $12 \mathrm{~mm}-20 \mathrm{~mm}$. Theo Gopalarishnan et al. (2013), chủng B. licheniformis (DAB1) đối kháng với $V$. paraheamolyticus với vòng kháng khuẩn $14-16 \mathrm{~mm}$ sau 24 giờ ủ. Bên cạnh đó, Trần Vũ Đình Nguyên và ctv. (2014) đã phân lập và định danh được chủng $B$. pumilis có khả năng đối kháng với $V$. owensii DY05 (tác nhân gây bệnh trên tôm hùm bông) bằng phương pháp khuếch tán đĩa thạch với đường kính kháng khuẩn là $29 \mathrm{~mm}$. Do vậy, trong nghiên cứu này đã phân lập được các chủng Bacillus sp. kháng với vi khuẩn $V$. parahaemolyticus ở mức từ kháng - kháng trung bình (Lorian, 1995). 
Bảng 3. Đường kính vòng kháng khuẩn chỉ thị $V$. parahaemolyticus

\begin{tabular}{clrrr}
\hline \multirow{2}{*}{ STT } & \multirow{2}{*}{ Chủng } & Đường kính vòng kháng (D-d, mm) & \multirow{2}{*}{ Giá trị trung bình (mm) } \\
\cline { 3 - 4 } & lần $\mathbf{~}$ & lần & \\
\hline 1 & CM3.1 & 13,4 & 12,7 & $13,05 \pm 0,49$ \\
3 & CM2.2 & 12,2 & 12,8 & $12,50 \pm 0,42$ \\
4 & BT1.1 & 10,1 & 9,7 & $9,90 \pm 0,28$ \\
5 & TV1.2 & 9,0 & 9,5 & $9,25 \pm 0,35$ \\
6 & NH1.2 & 9,3 & 10,0 & $9,65 \pm 0,49$ \\
7 & TB3.2 & 8,0 & 8,4 & $8,20 \pm 0,28$ \\
8 & TB3.3 & 8,0 & 7,9 & $7,95 \pm 0,07$ \\
9 & NH4.1 & 6,0 & 5,5 & $5,75 \pm 0,35$ \\
10 & DH2.1 & 5,0 & 5,2 & $5,10 \pm 0,14$ \\
11 & NH2.2 & 4,0 & 4,1 & $4,05 \pm 0,07$ \\
12 & CM1.1 & 4,8 & 5,0 & $4,90 \pm 0,14$ \\
13 & TB4.3 & 2,0 & 2,4 & $2,20 \pm 0,28$ \\
\hline
\end{tabular}

Ghi chú: Kháng: $\leq 9 \mathrm{~mm}$; Trung bình: $\geq 10$ - $13 \mathrm{~mm}$; Nhay: $\geq 14 \mathrm{~mm}$ (Lorian, 1995)
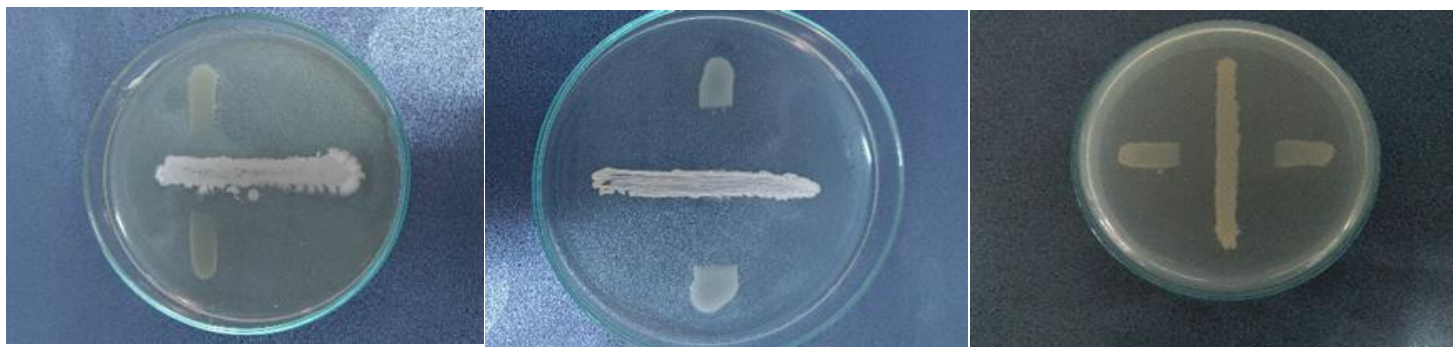

\section{Hình 2. Một số đường kính kháng khuẩn chỉ thị $V$. parahaemolyticus}

3.4. Hoạt tính kháng $V$. parahaemolyticus bằng phương pháp đồng nuôi cấy

3.4.1. Biến động mật độ vi khuẩn Bacillus CM3.1 và $V$. paraheamolyticus

Ở nghiệm thức $V$. paraheamolyticus nuôi đơn mật độ vi khuẩn có xu hướng tăng và đạt cao nhất lúc 48 giờ $(8,12 \log \mathrm{CFU} / \mathrm{mL})$, sau đó có xu hướng giảm dần và thấp nhất lúc 120 giờ $(6,77 \mathrm{Log}$ $\mathrm{CFU} / \mathrm{mL}$ ). Đối với nghiệm thức Bacillus CM3.1 nuôi đơn có xu hướng tương tự và đạt cao nhất lúc 72 giờ $(7,22 \log \mathrm{CFU} / \mathrm{mL})$. Còn riêng với nghiệm thức Bacillus CM3.1 nuôi chung với $V$. parahaemolyticus, mật độ vi khuẩn Bacillus CM3.1 đạt cao nhất lúc 96 giờ $(6,32 \log \mathrm{CFU} / \mathrm{mL})$; trong khi đó mật độ vi khuẩn $V$. parahaemolyticus thấp hơn có ý nghĩa thống kê $(4,61 \log C F U / m L)$ (p<0,05). Mật độ Bacillus CM3.1 thấp nhất lúc 24 giờ là $5,98 \log \mathrm{CFU} / \mathrm{mL}$ và mật độ $V$. parahaemolyticus là 6,65 Log CFU/mL. Mật độ $V$. parahaemolyticus trong nghiệm thức nuôi chung với Bacillus CM3.1 là thấp hơn có ý nghĩa thống kê so với các nghiệm thức nuôi đơn ( $\mathrm{p}<0,05)$ (Hình 3$)$.

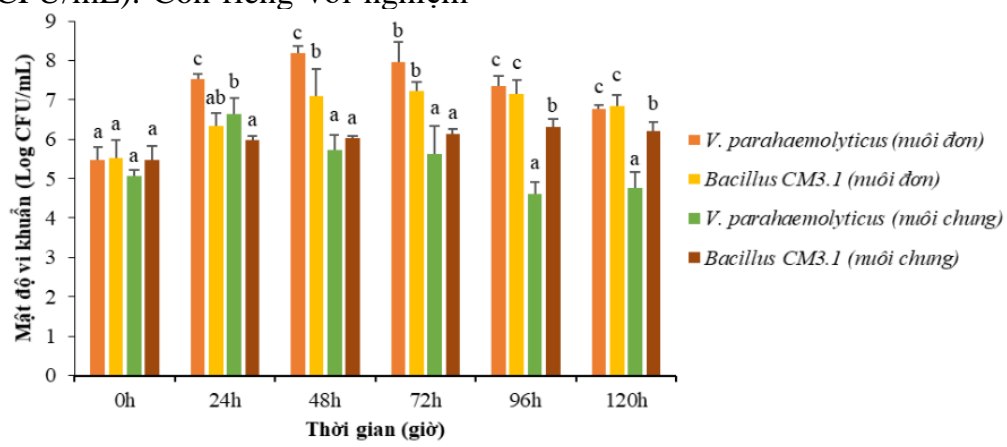

Hình 3. Vi khuẩn Bacillus CM3.1 kháng V. parahaemolyticus bằng phương pháp đồng nuôi cấy

Giá trị trên cùng một mốc thời gian của bốn nghiệm thức có chũ cái giống nhau thì không khác biệt có ý nghĩa thống kê $(p<0,05)$ 


\subsubsection{Biến động mật độ vi khuẩn Bacillus TV1.2 và $V$. paraheamolyticus}

Nghiệm thức $V$. parahaemolyticus nuôi đơn, vi khuẩn có xu hướng tăng và đạt cao nhất lúc 48 giờ $(8,18 \mathrm{Log} C F U / \mathrm{mL})$, sau đó giảm dần và thấp nhất lúc 120 giờ $(6,77 \log \mathrm{CFU} / \mathrm{mL})$. Đối với nghiệm thức Bacillus TV1.2 nuôi đơn đạt cao nhất lúc 72 giờ $(7,17 \log \mathrm{CFU} / \mathrm{mL})$ và thấp nhất lúc 24 giờ $(6,13$ Log $\mathrm{CFU} / \mathrm{mL}$ ). Khi kết hợp nuôi chung vi khuẩn
Bacillus TV1.2 với $V$. parahaemolyticus, mật độ vi khuẩn của cả 2 chủng đều có xu hướng giảm so với nuôi đơn. Ở thời điểm 48 giờ, mật độ vi khuẩn Bacillus TV1.2 và $V$. parahaemolyticus lần lượt biến động là 5,11 và $6,51 \log \mathrm{CFU} / \mathrm{mL}$ và ở thời điểm lúc 120 giờ là 6,38 và $5,19 \log C F U / m L$. Có thể nhận thấy khi mật độ Bacillus tăng thì Vibrio giảm. Sự khác biệt giữa các nghiệm thức có ý nghĩa thống kê $(\mathrm{p}<0,05)$ (Hình 4).

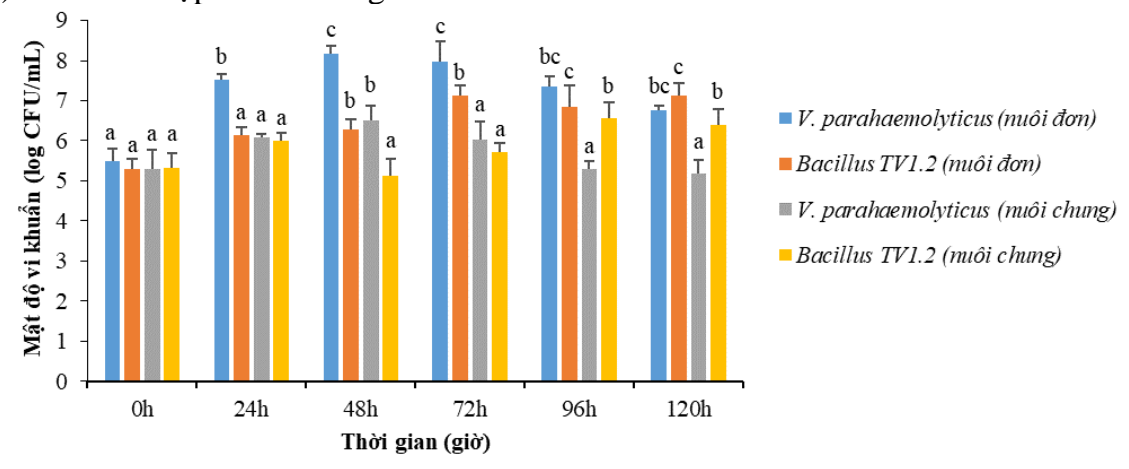

Hình 4. Vi khuẩn Bacillus TV1.2 kháng $V$. parahaemolyticus bằng phương pháp đồng nuôi cấy

Giá trị trên cùng một mốc thời gian của bốn nghiệm thức có chũ cái giống nhau thì không khác biệt có ý nghĩa thống kê $(p<0,05)$

\subsubsection{Biến động mật độ vi khuẩn Bacillus CM2.2 và $V$. paraheamolyticus}

Nghiệm thức $V$. parahaemolyticus nuôi đơn tăng và vi khuẩn đạt cao nhất lúc 48 giờ $(8,19 \log$ $\mathrm{CFU} / \mathrm{mL}$ ), sau đó có xu hướng giảm dần và thấp nhất lúc 120 giờ $(6,77 \mathrm{Log} \mathrm{CFU} / \mathrm{mL})$. Bên cạnh đó, nghiệm thức Bacillus CM2.2 nuôi đơn có xu hướng tăng và đạt cao nhất lúc 120 giờ $(7,36 \mathrm{Log}$ $\mathrm{CFU} / \mathrm{mL}$ ). Khi vi khuẩn Bacillus CM2.2 nuôi chung với $V$. parahaemolyticus đạt cao nhất lúc 120 giờ có mật độ Bacillus CM2.2 là 7,45 Log CFU/mL còn $V$. parahaemolyticus là $5,29 \mathrm{Log} \mathrm{CFU} / \mathrm{mL}$. Sự khác biệt có ý nghĩa thống kê (p<0,05) (Hình 5).

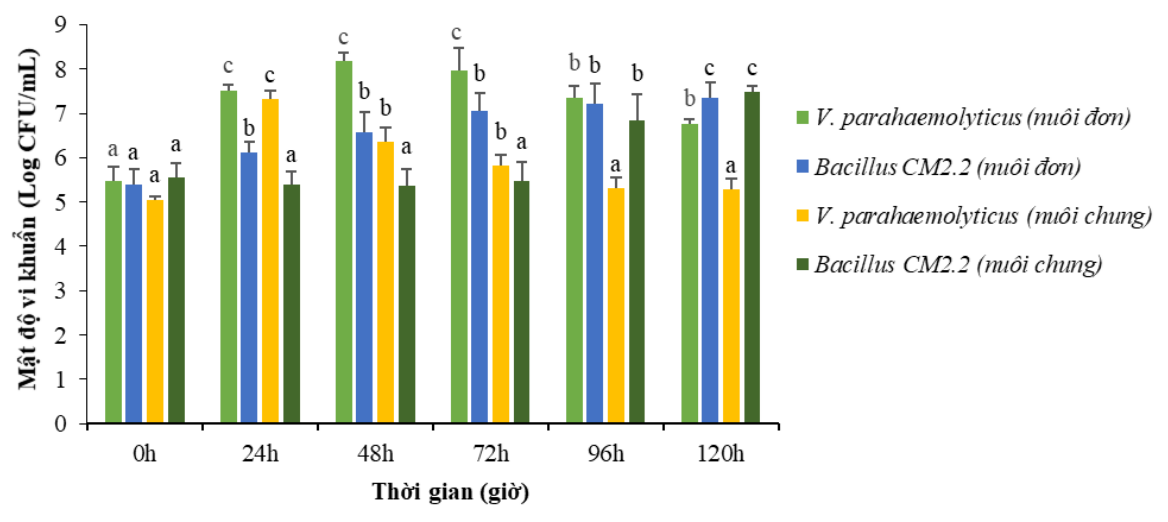

\section{Hình 5. Vi khuẩn Bacillus CM2.2 kháng V. parahaemolyticus bằng phương pháp đồng nuôi cấy}

Giá trị trên cùng một mốc thời gian của bốn nghiệm thức có chũ cái giống nhau thì không khác biệt có ý nghĩa thống kê $(p<0,05)$

Vaseeharan and Ramasamy (2003) cho rằng nồng độ $10^{9} \mathrm{CFU} / \mathrm{mL}$ B. subtilis BT23 sẽ ảnh hưởng đáng kể đến sự phát triển của $V$. harveyi $10^{3}$ $\mathrm{CFU} / \mathrm{mL}$. Kết quả thực nghiệm nuôi cấy cho thấy khi nồng độ $B$. subtilis BT23 tăng, sự tăng trưởng $V$. harveyi được kiểm soát trong điều kiện in vitro. Purivirojkul et al. (2007) cho rằng $B$. subtilis trong điều kiện in vitro và in vivo có khả năng ức chế được 
vi khuẩn $V$. harveyi. Bacillus sp. có khả năng sống trong môi trường năm ngày và có thể làm giảm mật độ vi khuẩn gây bệnh từ $10^{6}$ xuống $10^{5} \mathrm{CFU} / \mathrm{mL}$ trong thời gian 24 đến 48 giờ. Như vậy so với các nghiên cứu trước đây, các chủng Bacillus (CM3.1, TV1.2 và $\mathrm{CM} 2.2$ ) từ nồng độ $10^{5} \mathrm{CFU} / \mathrm{mL}$ có khả năng ức chế $V$. parahaemolyticus trong 120 giờ khảo sát.

\subsection{Hoạt tính enzyme ngoại bào}

Sau khi kiểm tra khả năng kháng khuẩn trên đĩa thạch, 13 chủng Bacillus đều có khả năng kháng $V$. parahaemolyticus. Trong đó, 5 chủng có đường kính kháng khuấn cao nhất bao gồm CM3.1, TV3.1, BT1.2, CM2.2, TV1.2 được chọn để đánh giá hoạt tính enzyme ngoại bào $\alpha$-amylase, protease và cellulase. Kết quả cho thấy có sự khác biệt có ý

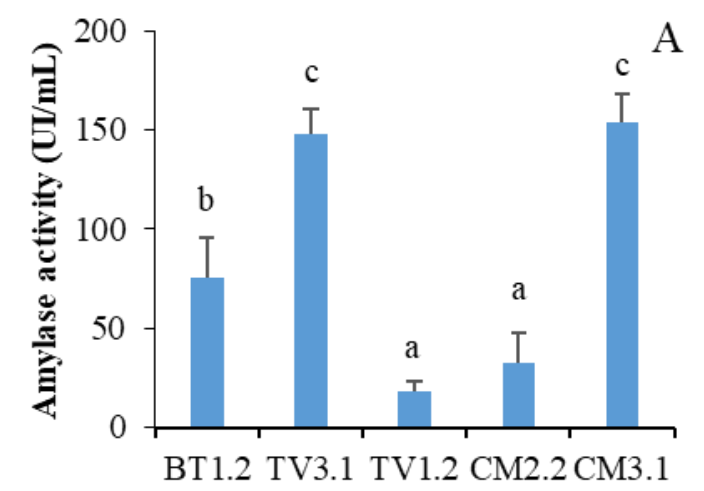

nghĩa thống kê về hoạt tính $\alpha$-amylase giữa các chủng được chọn. Hoạt tính $\alpha$-amylase cao nhất ở 2 chủng CM3.1 và TV3.1 (khoảng $153,7 \mathrm{UI} / \mathrm{mL}$ ) và cao hơn có ý nghĩa thống kê so với chủng so với 3 chủng còn lại. Trong đó, chủng có hoạt tính $\alpha$ amylase thấp nhất TV1.2 (18,3 UI/mL). Hoạt tính protease cao nhất ở chủng CM3.1 (140,9 UI/mL) và thấp nhất là chủng TV1.2 (129,7 UI/mL), tuy nhiên không có sự khác biệt có ý nghĩa thống kê về hoạt tính protease giữa các chủng khảo sát. Trong khi đó, chủng TV3.1 có khả năng tiết enzyme cellulase cao nhất $(943,4 \mathrm{UI} / \mathrm{mL})$ và cao hơn có ý nghĩa thống kê so với 4 chủng còn lại. Trong 4 chủng còn lại, chủng CM3.1 tiết ra nồng độ cellolase cao hơn 3 chủng còn lại. Trong 5 chủng khảo sát, chủng CM2.2 có khả năng tiết enzyme thấp nhất $(25,8 \mathrm{UI} / \mathrm{mL})$ (Hình 6).
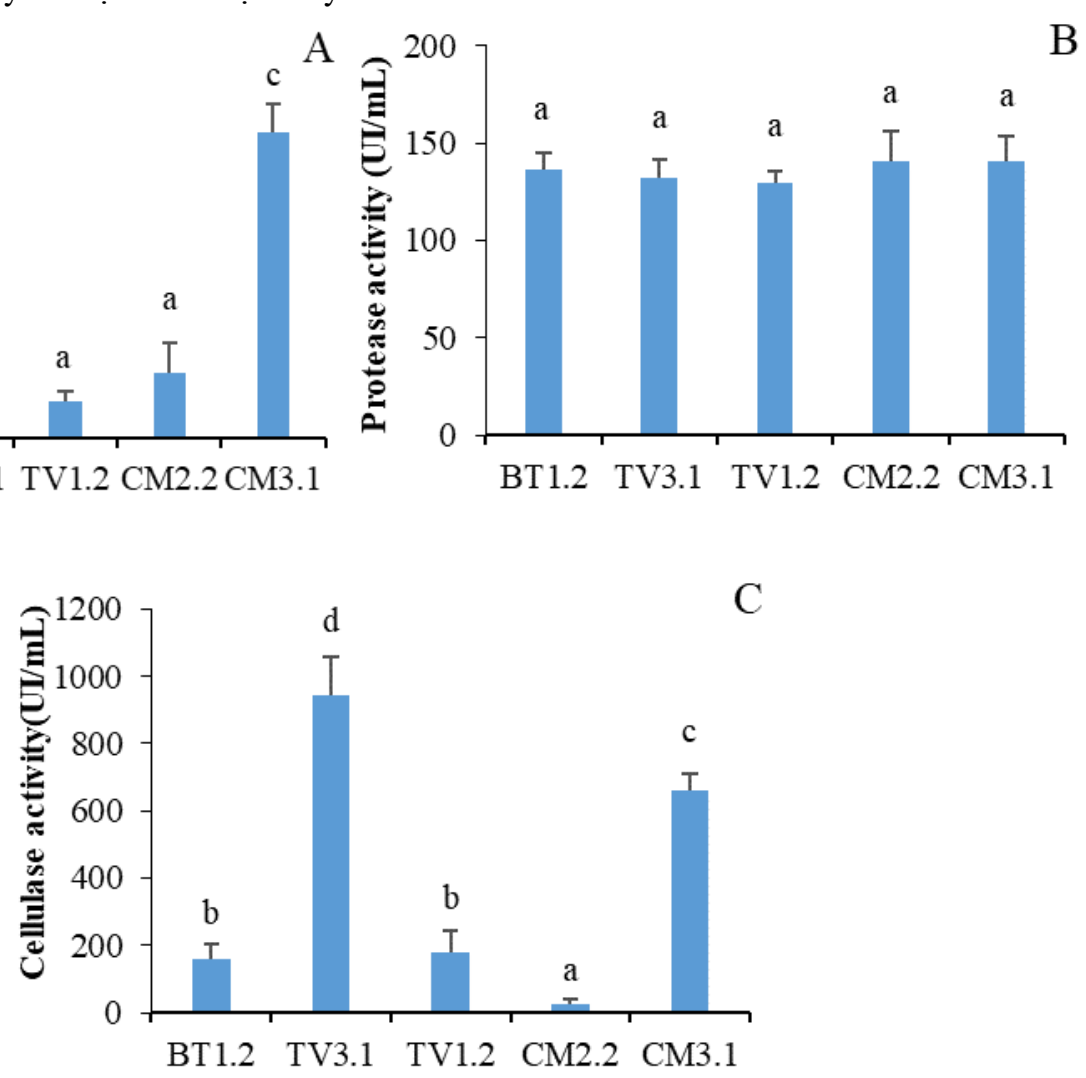

Hình 6. Hoạt tính enzyme $\alpha$-amylase $(\mathrm{A})$, protease $(\mathrm{B})$ và cellulase $(\mathrm{C})$ của các chủng vi khuẩn chọn lọc

Giá trị trên cùng một mốc thời gian của bốn nghiệm thức có chũ cái giống nhau thì không khác biệt có ý nghĩa thống kê $(p<0,05)$

Theo Lê Hải Yến và Nguyễn Đức Hiền (2016), khi chọn lọc các chủng vi khuẩn làm probiotic, khả năng sinh enzyme ngoại bào là một tiêu chí quan trọng bởi vì các enzyme ngoại bào đóng vai trò quan trọng trong việc hỗ trợ tiêu hóa thức ăn, giúp thức ăn dễ hấp thụ, phân hủy các thức ăn tồn đọng trong ao và vật nuôi tăng trọng tốt, bên cạnh đó còn có khả năng làm sạch môi trường. Theo $\mathrm{Ngô}$ Tự Thành và 
Bùi Việt Hà (2009), khi khảo sát hoạt tính enzyme ngoại bào của 236 chủng Bacillus phân lập từ các mẫu đất và nước thải khác nhau, chỉ có 2 chủng T20 và M27 thể hiện đầy đủ hoạt tính thủy phân các cơ chất tinh bột, $\mathrm{CMC}$, và gelatin, trong khi các dòng còn lại chỉ biểu hiện khả năng tinh bột và $\mathrm{CMC}$. Theo Lee et al. (2012), khi khảo sát tiềm năng probiotic của 4 dòng Bacillus spp. được phân lập từ nhiều nguồn khác nhau, chỉ có dòng Bacillus sp. SM2 thể hiện đầy đủ hoạt tính enzyme amylase, cellulase và protease, trong khi 3 dòng còn lại chỉ có dòng Bacillus sp. T4 và Bacillus sp. JSP1 thể hiện hoạt tính protease và cả 3 dòng này đều không thể hiện hoạt tính cellulase. Trong nghiên cứu này, cả 5 chủng khảo sát đều tiết enzyme $\alpha$-amylase, protease và cellulase ở các mức độ khác nhau. Nếu so sánh khả năng tiết 3 loại enzyme, Bacillus CM3.1 vượt trội hơn các chủng còn lại.

\section{6. Đánh giá độ an toàn sinh học}

Với khả năng kháng khuẩn cao nhất và hoạt tính enzyme cao so với các chủng còn lại, chủng Bacillus CM3.1 đã được chọn để thí nghiệm trên bể để xác định độ an toàn. Vi khuẩn Bacillus CM3.1 được sử dụng bổ sung trực tiếp vào môi trường nuôi với mật độ là $5 \times 10^{8} \mathrm{CFU} / \mathrm{mL}$ và tỉ lệ sống của tôm được ghi nhận sau 7 ngày. Kết quả cho tháy tỉ lệ sống của tôm đạt $100 \%$ đối với nghiệm thức bổ sung chủng Bacillus CM3.1, còn ở nghiệm thức không bổ sung chủng Bacillus CM3.1 thì tỉ lệ sống là $83 \%$. Mặc dù, chưa đánh giá được hiệu quả cải thiện tăng trưởng và sức khỏe của tôm, nhưng thí nghiệm này cho thấy mức độ an toàn sinh học cao và có thể có khả năng sử dụng chủng vi khuẩn Bacillus CM3.1 cho các thí nghiệm tiếp theo.

Sự hiện diện của vi khuẩn Bacillus có thể góp phần phân hủy các hợp chất hữu cơ dư thừa trong bể nuôi tôm làm duy trì môi trường nuôi ổn định, kích thích sử dụng thức ăn và sinh trưởng của tôm. Điều này phù hợp với các nghiên cứu có bổ sung vi khuẩn Bacillus, việc bổ sung vi khuẩn hữu ích không chỉ làm tăng khả năng phân giải các chất hữu cơ, làm sạch và ổn định môi trường nước mà còn làm tăng năng suất cao hơn so với ao nuôi không bổ dung vi khuẩn hữu ích (Phạm Thị Tuyết Ngân, 2012).

\section{KẾT LUẬN VÀ ĐỀ XUẤT}

\subsection{Kết luận}

Thí nghiệm đã chọn lọc được 13 chủng Bacillus spp. có khả năng kháng khuẩn $V$. parahaemolyticus và 5 chủng trong số 13 chủng có hoạt tính enzyme ngoại bào bao gồm $\alpha$-amylase, protease và cellulase từ 36 ao nuôi tôm quảng canh ở các tỉnh Cà Mau,
Bến Tre và Trà Vinh. Hai chủng Bacillus CM3.1 và TV1.3 có hoạt tính enzyme $\alpha$-amylase, protease, cellulase cao và có thể được sử dụng cho các nghiên cứu để phát triển chế phẩm sinh học cho nuôi tôm thẻ.

\section{2. Đề xuất}

Trong thòi gian tới tiếp tục nghiên cứu các chủng Bacillus tiềm năng có khả kháng khuẩn cao nhằm phát triển chế phẩm sinh học phục vụ cho nuôi trồng thủy sản.

\section{LỜI CẢM TẠ}

Đề tài này được tài trợ bởi Dự án Nâng cấp Trường Đại học Cần Thơ VN14-P6 bằng nguồn vốn vay ODA từ Chính Phủ Nhật Bản.

\section{TÀI LIỆU THAM KHẢO}

Abd-Elhalem, B. T., El-Sawy, M., Gamal, R. F., \& Abou-Taleb, K. A. (2015). Production of amylases from Bacillus amyloliquefaciens under submerged fermentation using some agroindustrial byproducts. Annals of Agricultural Sciences, 60(2), 193-202.

Balcázar, J. L., D. Vendrell, I. De Blas, D. Cunninghem, D. Vandrell \& J. Z. Muzquiz (2006). The role of probiotic in aquaculture. Veterinary Microbiology, (114), 173 - 186.

Boottanun, P., Potisap, C., Hurdle, J. G. and Sermswan, R. W. (2017). Secondary metabolites from Bacillus amyloliquefaciens isolated from soil can kill Burkholderia pseudomallei. AMB Express, 7(1), 16.

Burford, M.A., Peterson, E.L., Baiano J.F.C., \& Preston, N.P. (1998). Bacteria in shrimp pond sediments, their role in mineralizing nutrients and some suggested sampling strategies. Aquaculture Research 29, 843-849.

Fernandes, S., Kerkar, S., Leitao, J., \& Mishra, A. (2019). Probiotic role of salt pan bacteria in enhancing the growth of whiteleg Shrimp, Litopenaeus vannamei. Probiotics and Antimicrobial Proteins, 11(4), 1309 - 1323.

Ghose, T.K. (1987). Measurement of cellulose activities. Pure Appl Chem 59(2), 257 - 268

Hucker, G. J. \& Conn, H. J. (1923). Methods of Gram Staining. New York State Agricultural Experiment Station Technical Bulletin, 93, 3 - 37.

Hutt, P., Shchepetova, J., Loivukene, K., Kullisaar, T., \& Mikelsaar, M. (2006). Antagonistic activity of probiotic lactobacilli and bifidobacteria against entero- and uropathogens. Journal of Applied Microbiology, 100(6), 1324 - 1332.

Huynh, T. G, Chi, C. C, Nguyen, T. P., Hien, T. T. T, Cheng, A. C., \& Liu, C. H. (2018). Effects of synbiotic containing Lactobacillus plantarum 7 - 
40 and galactooligosaccharide on the growth performance of white shrimp, Litopenaeus vannamei. Aquaculture Research, 49, 2416 - 2428.

Kewcharoen, W. \& Srisapoome, P. (2019). Probiotic effects of Bacillus spp. from Pacific white shrimp (Litopenaeus vannamei) on water quality and shrimp growth, immune responses, and resistance to Vibrio parahaemolyticus (AHPND strains). Fish \& Shellfish Immunology, 94, 175 - 189.

Lê Hải Yến \& Nguyễn Đức Hiền. (2016). Khảo sát đặc tính probiotic các chủng vi khuẩn Bacillus subtilis phân lập tại các tỉnh đồng bằng sông Cửu Long. Tạp chí khoa hoc đại hoc Cần Tho, Số chuyên đề: Nông nghiệp (2), 26 - 32.

Lee, J., Park, I., Choi, Y. \& Cho, J. (2012). Bacillus strains as feed additives: In vitro evaluation of its potentinal probiotic properties. Revista Colomiana de Ciencias Pecuarias, 25, 577 - 585.

Lertcanawanichakul M. \& Sawangnop S. (2011). A comparison of two methods used for measuring the antagonistic activity of Bacillus species. Walailak Journal of Science Technology, 5,161-171.

Lorian, V. (1995). Antibiotics in laboratory medicine. In: J. F. Acar, and F. W. Goldstein (Eds.). Disk susceptibility test (4 ${ }^{\text {th }}$ ed.). London: William and Walkins Awaverly, p.1.

Mahdhi, A., Harbi, B., Esteban, M. Á., Chaieb, K., Kamoun, F., \& Bakhrouf, A. (2010). Using mixture design to construct consortia of potential probiotic Bacillus strains to protect gnotobiotic Artemia against pathogenic Vibrio, Biocontrol Science and Technology, 20(9), 983-996.
Miller, G. L. (1959). Use of dinitrosalicylic acid reagent for determination of reducing sugars. Analytical Chemistry, 3, 426 - 428.

Ngô Tự Thành \& Bùi Thị Việt Hà. (2009). Nghiên cứu hoạt tính enzyme ngoại bào của một số dòng Bacillus mới phân lập và khả năng ứng dụng chúng trong xử lý nước thải. Tạp chí Khoa học Đại học Quốc gia Hà Nội, Khoa tự nhiên và công nghê, 25, 101 - 106.

Phạm Thị Tuyết Ngân. (2012). Nghiên cứu vi khuẩn chuyển hóa giai đoạn trong bùn đáy ao nuôi tôm sú (Penaeus monodon) (Luận án tiến sĩ). Trường Đại học Cần Thơ.

Somsiri, T., Oanh, D. T. H., Chinabut, S., Phuong, N. T., Shariff, M., Yusoff, F. M., ... \& Teale, A. (2006). A simple device for sampling pond sediment. Aquaculture, 258(1-4), 650-654.

Thongjun, J., Tansila, N., Panthong, K., Tanskul, S., Nishibuchi, M. \& Vuddhakul, V. J. A. O. M. (2016). Inhibitory potential of biosurfactants from Bacillus amyloliquefaciens derived from mangrove soil against Vibrio parahaemolyticus, 66(3), 1257 - 1263.

Trần Vũ Đình Nguyên, Nguyễn Văn Duy \& Vũ Ngọc Bội. (2014). Hoạt tính probiotic, đặc điểm phân loại và điều kiện nuôi thích hợp của chủng Bacillus pumilus B3.10.2 phân lập từ tôm hùm bông. Tạp chí Khoa học - Công nghệ Thủy sản, 1, 182-183.

Yun, L., Yu, Z., Li, Y., Luo, P., Jiang, X., Tian, Y. \& Ding, X. (2019). Ammonia nitrogen and nitrite removal by a heterotrophic Sphingomonas sp. strain LPN080 and its potential application in aquaculture. Aquaculture, 500, 477 - 484. 